\title{
NIOBIUM IN TUNGSTEN-3.5 NICKEL-1.5 IRON ALLOY
}

\author{
R. L. Ludwig
}

August 1975

OAK RIDGE Y-12 PLANT OAK RIDGE, TENNESSEE

prepared for the U.S. ENERGY RESEARCH AND DEVELOPMENT ADMINISTRATION under U.S. GOVERNMENT Contract W-7405 eng 26 


\section{DISCLAIMER}

This report was prepared as an account of work sponsored by an agency of the United States Government. Neither the United States Government nor any agency Thereof, nor any of their employees, makes any warranty, express or implied, or assumes any legal liability or responsibility for the accuracy, completeness, or usefulness of any information, apparatus, product, or process disclosed, or represents that its use would not infringe privately owned rights. Reference herein to any specific commercial product, process, or service by trade name, trademark, manufacturer, or otherwise does not necessarily constitute or imply its endorsement, recommendation, or favoring by the United States Government or any agency thereof. The views and opinions of authors expressed herein do not necessarily state or reflect those of the United States Government or any agency thereof. 


\section{DISCLAIMER}

Portions of this document may be illegible in electronic image products. Images are produced from the best available original document. 
Reference to a company or product name does not imply approval or recommendation of the product by Union Carbide Corporation or the U.S. Energy Research and Development Administration to the exclusion of others that may meet specifications.

Printed in the United States of America. Available from National Technical Information Service

U.S. Department of Commerce

5285 Port Royal Road, Springfield, Virginia 22161

Price: Printed Copy $\$ 4.00$; Microfiche $\$ 2.25$

This report was prepared as an account of work sponsored by the United States Government. Neither the United States nor the Energy Research and Development Administration, nor any of their employees, nor any of their contractors, subcontractors, or their employees, makes any warranty, express or implied, or assumes any legal liability or responsibility for the accuracy, completeness or usefulness of any information, apparatus, product or process disclosed, or represents that its use would not infringe privately owned rights. 


\title{
NIOBIUM IN TUNGSTEN-3.5 NICKEL-1.5 IRON ALLOY
}

\author{
R. L. Ludwig \\ Metallurgical Development Department \\ $Y-12$ Development Division
}

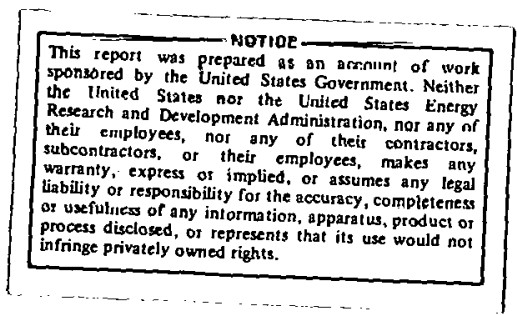

Oak Ridge Y.12 Plant

P. O. Box Y, Oak Ridge, Tennessee 37830

Prepared for the US Energy Research and Development Administration

Uide US Covornment rentrast W-7405-eng-26 


\begin{abstract}
Tungsten-3.5 nickel-1.5 iron alloy normally possesses a high degree of tensile ductility and can be liquid-phase sintered in dry hydrogen. When prepared with tungsten from certain sources, the alloy may become brittle or develop surface blisters during sintering. The addition of niobium in concentrations of 200 to 2000 parts per million to alloys susceptible to these difficulties has served to overcome the embrittlement and sintering problems. Excessive quantities of niobium, however, tend to deteriorate the tensile properties of the alloy.
\end{abstract}




\section{CONTENTS}

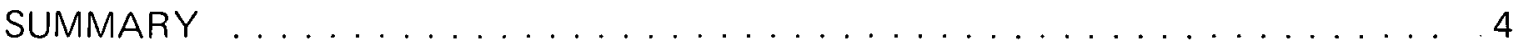

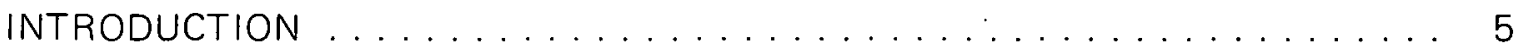

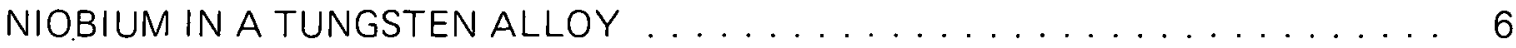

Experimental Results . . . . . . . . . . . . . . . . . . . . . . 6

Low Tensile Ductility in Reprocessed Tungsten-3.5 Nickel-1.5 Iron Alloy . . . . . 6

Blistering in High-Green-Strength Tungsten-3.5 Nickel-1.5 Iron Alloy. . . . . . . 10

Discussion of Results . . . . . . . . . . . . . . . . . . . . 16

Low Tensile Ductility in Reprocessed Tungsten-3.5 Nickel-1.5 Iron Alloy . . . . 16

Blistering in High-Green-Strength Tungsten-3.5 Nickel-1.5 Iron Alloy . . . . . . . 17

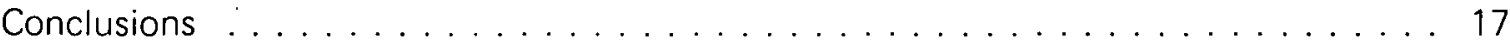

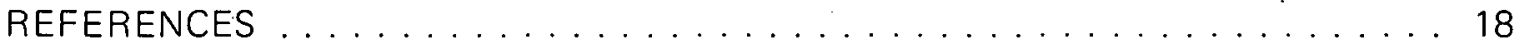




\section{SUMMARY}

Tungsten-3.5 nickel-1.5 iron (W-3.5 Ni-1.5 Fe) alloy normally shows a high measure of tensile ductility and can be liquid-phase sintered satisfactorily in dry hydrogen. However, at the Oak Ridge Y-12 Plant, (a) tungsten powder procured from certain sources yielded alloy which was brittle, or blistered on the surface during sintering. This report describes experiments directed toward overcoming these two problems. Reactive metal additions, niobium in particular, proved to be solutions to both difficulties. Maximum tensile ductility recovery was achieved by the addition of 500 to 1000 parts per million (ppm) of niobium; however, excessive amounts of niobium ( 0.7 to $1.1 \mathrm{wt} \%$ ) caused both tensile and impact próperties to deteriorate.

Elimination of blistering during sintering accompanied the addition of 1000 to $2000 \mathrm{ppm}$ niobium. This problem is normally controlled in production sintering by the use of a wet-hydrogen sintering atmosphere, but blistering is only inhibited by this method and will appear it the alloy is reheated to the liquid phase in dry hydrogen. Niobium addition provides a lasting suppression of blistering.

Appearance of the microstructure of the alloy suggests that the limit of niobium solubility is 500 to $1000 \mathrm{ppm}$ niobium. It is believed that this dissolved niobium reacts with an impurity or impurities present in the alloy in small amounts to prevent the occurrence of brittleness and blistering.

(a) Operated by the Union Carbide Corporation's Nuclear Division for the US Energy Research and Development Administration. 


\section{INTRODUCTION}

Tungsten-nickel-iron liquid-phase-sintered alloys with tungsten contents of 80 to 92 wt \% and a nickel-to-iron ratio of 7:3 are known to possess high tensile ductility. (1) Work at the Oak Ridge Y-12 Plant has shown that the $95 \mathrm{wt} \%$ tungsten alloy (W-3.5 Ni-1.5 Fe) also possesses this characteristic (2) and that the high-tensile-elongation property is maximized only after the application of a post-sintering heat treatment. Occasionally, however, for reasons which are not yet well established, even properly heat-treated W-3.5 Ni-1.5 Fe alloy made from certain tungsten powders will show little or no tensile elongation:

As an associated problem, when the $\mathrm{W}-3.5 \mathrm{Ni}-1.5 \mathrm{Fe}$ alloy is prepared using a given high-green-strength tungsten powder and is liquid-phase sintered in dry hydrogen, blisters form on the outer surface of the compact, and low tensile ductility may result. A wet hydrogen sintering atmosphere eliminates blistering and the tensile elongation of material sintered in this manner and heat treated is very good.

Microstructures of all of the alloys (ductile and brittle) are identical, consisting of rounded tungsten grains in a matrix phase. Fractographs of less ductile alloys show mostly clean separation at the tungsten/matrix interface rather than the predominantly transgranular fractures of the high-elongation materials. It is known that small fractions of $1 \mathrm{ppm}$ hydrogen will cause low tensile ductility, but the heat treatment referred to previously removes almost all hydrogen: Indications, then, point to one or more impurities, present in small quantities, as being the cause of both the low tensile ductility and blistering.

This observation suggests that a possible solution to the problems might be a reactive metal addition which would either eliminate the impurities or change the form in which they exist. 


\section{NIOBIUM IN A TUNGSTEN ALLOY}

\section{EXPERIMENTAL RESULTS}

\section{Low Tensile Ductility in Reprocessed Tungsten-3.5 Nickel-1.5 Iron Alloy}

The problem of low tensile ductility in W-3.5 Ni-1.5 Fe alloy has been associated with alloy - prepared from certain lots of tungsten powder which had been reprocessed by a manufacturer. As a means of identification, the term "reprocessed tungsten powder" will be used. It was purchased to the chemical specification given in Table 1. Later analyses at the Y-12 Plant by the Leco method revealed oxygen contents of up to $2500 \mathrm{ppm}$, well in excess of the $500 \mathrm{ppm}$ specified maxımum. However, reanalysis by the neutron activation method more consistently showed oxygen levels of $1000-1100 \mathrm{npm}$ This methond employs a sample that is 70 to 80 times larger than the Leco analysis and probably tends to average out chemical inhomogeneities inherent among small samples. Other impurities in excess of the specification have not been detected. However, phosphorus (unspecified, but believed to contribute to the embrittlement of tungsten) has been detected by the mass spectrograph in amounts on the order of a few tens of ppm.

Tensile elongation of an alloy prepared from reprocessed tungsten powder varies from zero up to a few percent; whereas, with other tungsten powders, values of 20 to $30 \%$ are readily attainable. The reactive materials selected as additives in an attempt to restore the ductility were: titanium and niobium metal and zirconium hydride. All three were in the form of -325 mesh powder with purities, respectively, of 99.9, 99.7. and $99.5 \%$.

Bars with titanium additions of $0,100,300$, and 500 ppm were prepared and tensile tested in the as-sintered condition to test the hypothesis that if the titanium addition improved ductility it also would eliminate the requirement for the vacuum heat treatment. Negligible tensile elongation was realized in all tour alloys, but the titanium-containing test bars produced results superior to the bar containing no titanium.

Additional bars were prepared, one containing 1200 ppm niobium and $1200 \mathrm{ppm}$ zirconium hydride for the other. These bars received a 36 -hour, $1100^{\circ} \mathrm{C}$ vacuum heat treatment prior to testing. Tensile tests of these bars showed an elongation of. $25 \%$ for the niobiumcontaining alloy and $15 \%$ tor the alloy with zirconium hydride.

In view of these encouraging preliminary tests, it was decided to rerun the experiments with the niobium

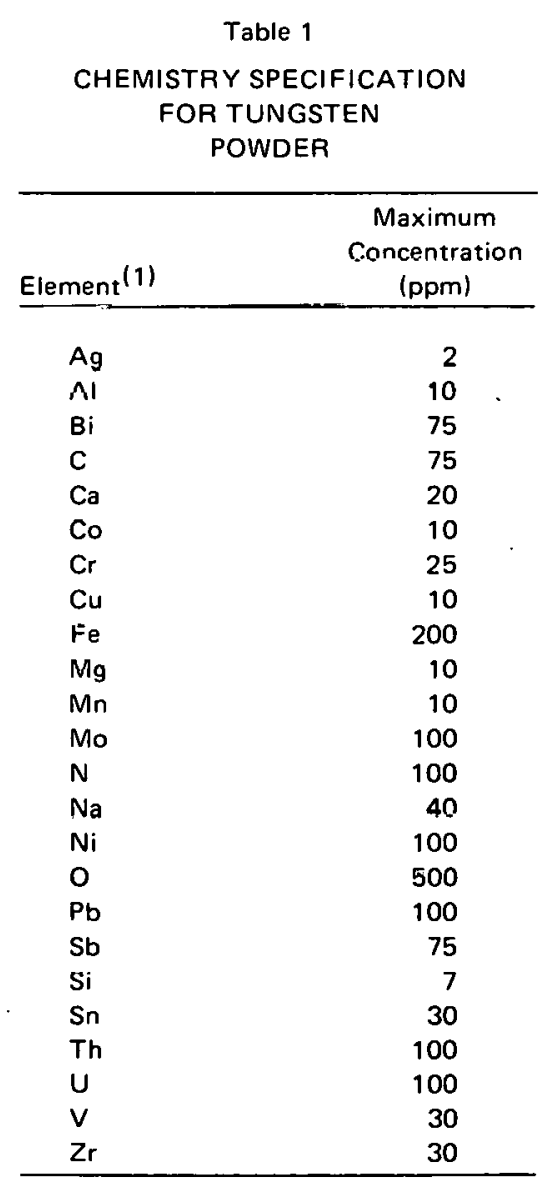

(1) Tungsten-99.9\%, minimum; no element, except tungsten, in excess of $1000 \mathrm{ppm}$. 
addition; and, if favorable results were achieved, to determine the minimum niobium concentration to achieve maximum ductility. Also to be examined was the effect of greater-than-required niobium additions.

A single batch of reprocessed W-3.5 Ni-1.5 Fe alloy was divided into two portions. To one was added 1200 ppm niobium powder; none was added to the other. Four bars, pressed from the niobium-containing blend (approximately $19 \mathrm{~mm} \mathrm{D} \times 150 \mathrm{~mm} \mathrm{~L}$ ), and three bars of the original blend were isostatically pressed at $207 \mathrm{MPa}$. All seven bars were sintered simultaneously in wet hydrogen at $1470^{\circ} \mathrm{C}$ and were heat treated together in vacuum at $1200^{\circ} \mathrm{C}$ for six hours. Two tensile bars ( $6.40 \mathrm{~mm}$ gage $D$ and 25.4 gage $L$ ) were machined from each rod. The gage lengths of the bars were polished lengthwise to eliminate the possibility of the machining grooves acting as stress risers. The tensile test results appear in Table 2 and reveal the beneficial effect of the niobium upon the alloy properties. The principal difference observed in a scanning electron microscopic examination of fractures representative of the two groups of specimens was in the bond between the matrix and tungsten particles. The low-ductility tensile bars fractured almost entirely intergranularly at the matrix/particlc bond, with little or no evidence of adhesion, although the matrix itself did

Table 2

TENSILE-TEST RESULTS OF REPROCESSED TUNGSTEN-3.5 NICKEL-1.5 IRON ALLOY WITH AND WITHOUT THE ADDITION OF $1200 \mathrm{ppm}$ NIOBIUM

\begin{tabular}{|c|c|c|c|}
\hline $\begin{array}{c}\text { Ultimate Tensile } \\
\text { Strength } \\
(\mathrm{MPa})(1) \\
\end{array}$ & $\begin{array}{l}\text { Tensile Yield } \\
\text { Strength (2) } \\
\text { (MPa) }\end{array}$ & $\begin{array}{c}\text { Elongation (3) } \\
(\%)\end{array}$ & $\begin{array}{c}\text { Reduction } \\
\text { in Area } \\
(\%)\end{array}$ \\
\hline \multicolumn{4}{|c|}{ Without Niobium } \\
\hline $493 \pm 32^{(4)}$ & (5) & $<1$ & 0 \\
\hline \multicolumn{4}{|c|}{ With $1200 \mathrm{ppm}$ Niobium } \\
\hline $942 \pm 2$ & $615 \pm 11$ & $22.9 \pm 1.5$ & $21.0 \pm 1.8$ \\
\hline
\end{tabular}

(1) $1 \mathrm{MPa}=0.145 \mathrm{ksi}$.

(2) At $0.2 \%$ offset.

(3) lil une incli.

(4) $95 \%$ confidence limits on mean.

(5) Broke before reaching the yield stress. not appear to be embrittled. The high-ductility bars showed a large proportion of transgranular fracture of the tungsten particles, good matrix/particle adhesion, and a high matrix ductility.

Figure 1 reveals the microstructure of the alloys with and without the niobium addition. The large, gray niobium particles in View b were relatively few in number. Most of the undissolved niobium was present as the smaller particles visible in the matrix of this microstructure. The two specimens corresponding to the photomicrographs in Figure 1 were analyzed by electron-beam microprobe. In the nonniobiumcontaining sample, the iron and nickel concentrations in the tungsten particles were in the range of 1000 to $3000 \mathrm{ppm}$, each with the iron usually present in greater amounts. In the niobium-containing specimen, about $600 \mathrm{ppm}$ niobium was found in the tungsten while the matrix concentration contained approximately $4000 \mathrm{ppm}$ niobium. The large, gray niobium particles contained no detectable amount of any additional element other than oxygen, which was present in a concentration estimated at 15-20 wt \%. This concentration roughly approximates $\mathrm{NbO}$ stoichiometry. The matrix composition in both cases was approximately $50 \mathrm{wt} \%$ nickel, $20 \mathrm{wt} \%$ iron, and the balance tungsten. Both specimens were also scanned by an image analyzer 


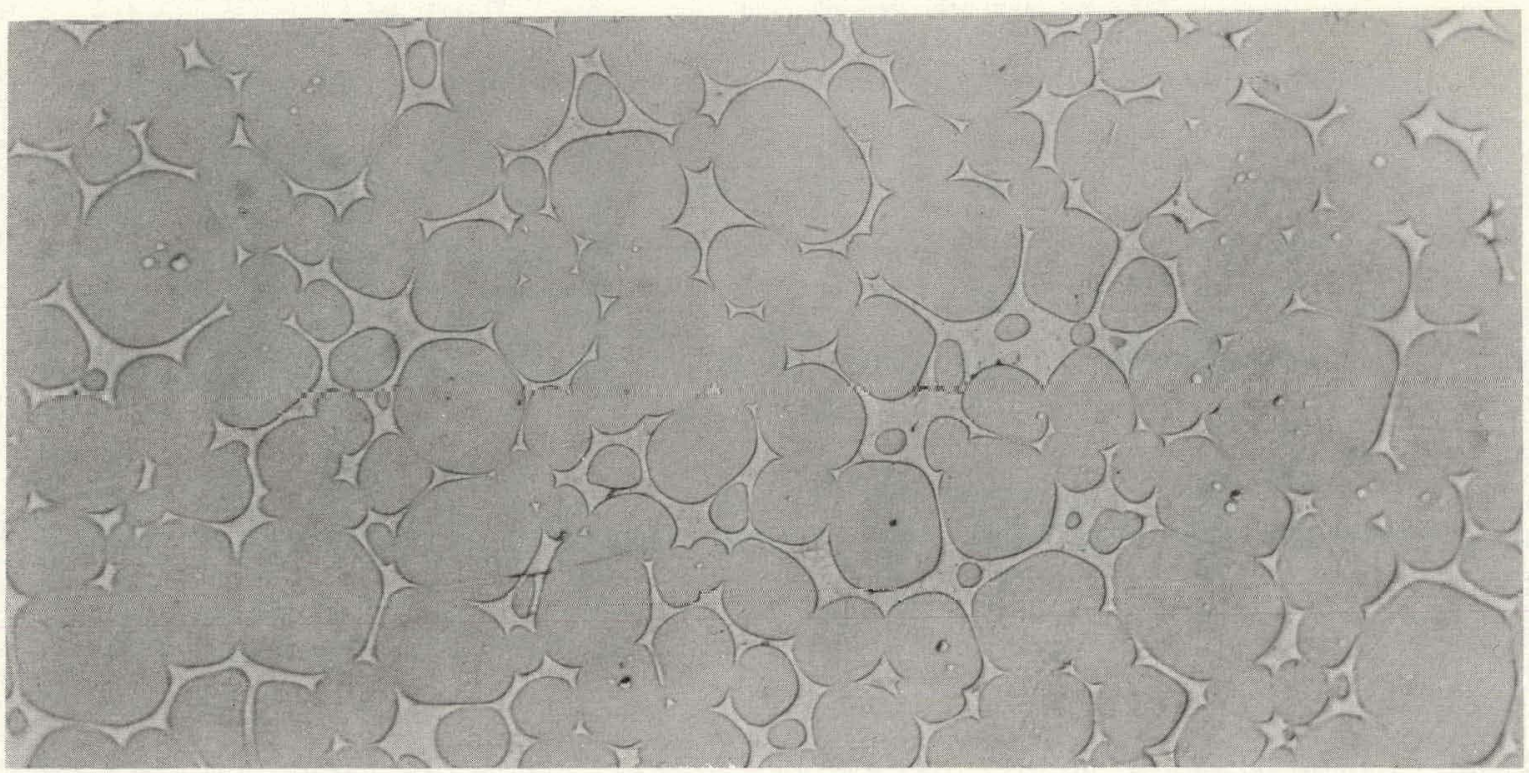

(a) Without $1200 \mathrm{ppm}$ Niobium.

I199-1E

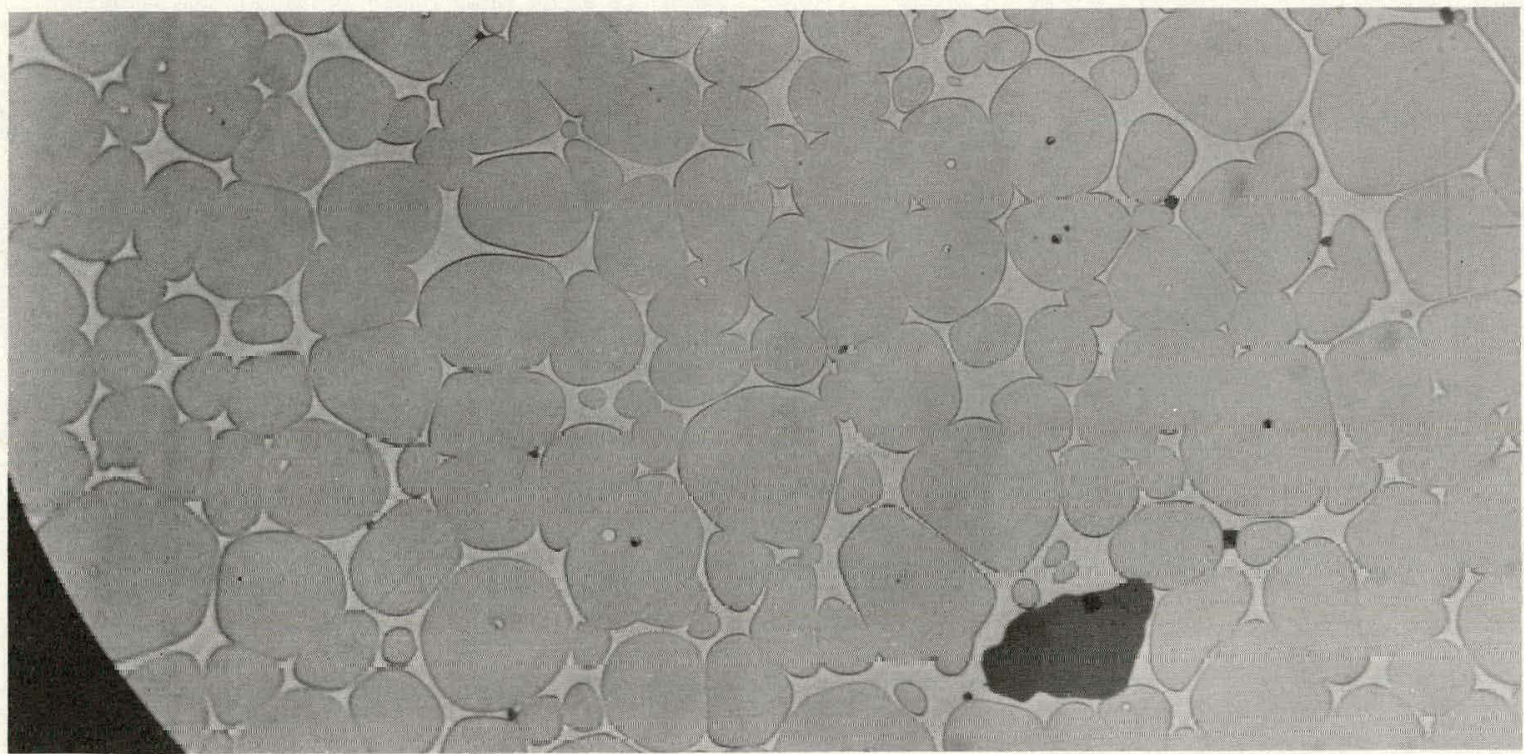

(h) With $1200 \mathrm{ppm}$ Niabium.

I199-2D

Figure 1. MICROSTRUCTURE OF REPROCESSED TUNGSTEN-3.5 NICKEL-1.5 IRON ALLOY, WITHOUT AND WITH THE ADDITION OF 1200 ppm NIOBIUM. (Unetched; Bright Field Illumination; 250X)

[Quantimet(b)]. The nonniobium specimen showed an average matrix volume fraction of 0.132. Values for the specimen with niobium were 0.116 matrix and 0.0013 niobium particles.

(b) A product of IMANCO Image Analyzing Computers, Ltd, Monsey, NY 10952. 
Table 3

CHEMICAL ANALYSIS OF
REPROCESSED
TUNGSTEN POWDER
(All Values in ppm
Except as Noted)

\begin{tabular}{|c|c|}
\hline Element & $\begin{array}{c}\text { Amount } \\
\text { Present } \\
\end{array}$ \\
\hline $\mathrm{Ag}$ & $<1$ \\
\hline $\mathrm{Al}$ & $<4$ \\
\hline B & $<1$ \\
\hline $\mathrm{Bi}$ & $<10$ \\
\hline $\mathrm{Ca}$ & $<2$ \\
\hline Co & $<10$ \\
\hline $\mathrm{Cr}$ & 10 \\
\hline Cs & $<200$ \\
\hline $\mathrm{Cu}$ & $<2$ \\
\hline $\mathrm{Fe}$ & 50 \\
\hline $\mathrm{Mg}$ & $<2$ \\
\hline $\mathrm{Mn}$ & 4 \\
\hline Mo & $<20$ \\
\hline $\mathrm{Na}$ & $<20$ \\
\hline $\mathrm{Ni}$ & 80 \\
\hline $\mathrm{Pb}$ & $<10$ \\
\hline $\mathrm{Rb}$ & $<100$ \\
\hline $\mathrm{Sb}$ & $<20$ \\
\hline $\mathrm{Si}$ & 6 \\
\hline Sn & $<10$ \\
\hline Th & $<100$ \\
\hline$u$ & $<100$ \\
\hline v & $<20$ \\
\hline $\mathrm{Zr}$ & $<20$ \\
\hline Oxyyen (\%) & 0.072 \\
\hline Nitrogen $(\%)$ & 0.001 \\
\hline
\end{tabular}

Following this investigation of the alloys containing $1200 \mathrm{ppm}$ niobium, further experiments were performed to determine the minimum niobium concentration needed to accomplish recovery of ductility and to ascertain the effects of excessive quantities of niobium. To implement the first objective, sintered alloy discs $(165 \mathrm{~mm} \mathrm{D} \times 38 \mathrm{~mm} \mathrm{~T}$ ) were prepared from reprocessed tungsten of the analysis given in Table 3 . Discs were made with niobium additions of $0,200,500,1000$, and $2000 \mathrm{ppm}$. The discs were isostatically pressed at $207 \mathrm{MPa}$ and sintered as a group in hydrogen at $1470^{\circ} \mathrm{C}$. Blanks for the tensile and impact specimens and oxygen and hydrogen samples were cut from each disc and all were annealed in a single run in vacuum at $1200^{\circ} \mathrm{C}$ for four hours. Table 4 reports the chemical analyses of the five alloys. Full recovery of the niobium additions is evident as is an apparent tendency of carbon and oxygen to increase with the niobium.

In Table 5, the mechanical properties are presented. Although substantial improvement in properties resulted from the 200 $\mathrm{ppm}$ niobium addition, 500 to $1000 \mathrm{ppm}$ niobium yielded the maximum improvement in tensile properties and 1000 to 2000 $\mathrm{ppm}$ niobium optimized the impact properties. Figure 2 displays photomicrographs of the microstructures of the five alloys. No evidence of niobium was observed in the $200 \mathrm{ppm}$ niobium alloy, but a few small residual particles were present in the $500 \mathrm{ppm}$ alloy. Although only an occasional large niobium particle was detected in the $1000 \mathrm{ppm}$ alloy, many were seen in the $2000 \mathrm{ppm}$ alloy. What is apparently the limit of solubility of niobium in the alloy closely coincides with the optimization of properties.

The minimum concentration of niobium to restore mechanical properties is desirable from the viewpoint of maximizing density; however, because of the possibility of further improving properties, an experiment was run to examine the effects of increased niobium

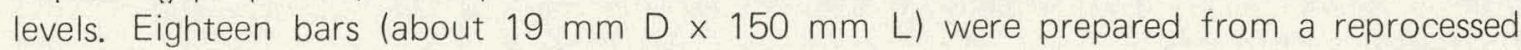

Table 4

CHEMICAL ANALYSES OF REPROCESSED TUNGSTEN-3.5 NICKEL-1.5 IRON ALLOY WITH CERTAIN NIOBIUM ADDITIONS

\begin{tabular}{|c|c|c|c|c|c|c|c|c|}
\hline \multirow{2}{*}{$\begin{array}{l}\text { Nominal } \\
\text { Niobium } \\
\text { Content } \\
\text { (ppm) }\end{array}$} & \multirow{2}{*}{$\begin{array}{c}\text { Tungsten } \\
\text { (wt \%) }\end{array}$} & \multirow{2}{*}{$\begin{array}{l}\text { Nickel } \\
\text { (wt \%) }\end{array}$} & \multirow{2}{*}{$\begin{array}{l}\text { Iron } \\
\text { (wt \%) }\end{array}$} & \multirow{2}{*}{$\begin{array}{c}\text { Niobium } \\
\text { (wt \%) }\end{array}$} & \multirow{2}{*}{$\begin{array}{c}\text { Carbon } \\
(\mathrm{ppm})\end{array}$} & \multicolumn{2}{|c|}{$\begin{array}{c}\text { Hydrogen } \\
\text { (ppm) }\end{array}$} & \multirow{2}{*}{$\begin{array}{c}\text { Oxygen } \\
\text { (ppm) }\end{array}$} \\
\hline & & & & & & Bulk & Total & \\
\hline 0 & 95.24 & 3.52 & 1.48 & - & 6 & 0.04 & 0.14 & 2 \\
\hline $200^{(1)}$ & 94.38 & 3.72 & 1.58 & 0.02 & 13 & 0.26 & 0.32 & 2 \\
\hline 500 & 94.57 & 3.46 & 1.44 & 0.05 & 4 & 0.03 & 0.09 & 5 \\
\hline 1000 & 94.32 & 3.52 & 1.46 & 0.09 & 7 & 0.08 & 0.16 & 9 \\
\hline 2000 & 94.97 & 3.55 & 1.49 & 0.20 & 21 & 0.06 & 0.11 & 30 \\
\hline
\end{tabular}

(1) Spectrographic analysis showed $50 \mathrm{ppm}$ molybdenum in this alloy. 
Table 5

MECHANICAL PROPERTIES OF REPROCESSED TUNGSTEN-3.5 NICKEL-1.5 IRON

ALLOY WITH NIOBIUM ADDITIONS

\begin{tabular}{|c|c|c|c|c|c|c|}
\hline \multirow{2}{*}{$\begin{array}{c}\text { Nominal } \\
\text { Niobium } \\
\text { Content } \\
\text { (pprm) }\end{array}$} & \multirow{2}{*}{$\begin{array}{l}\text { Ultimate } \\
\text { Tensile } \\
\text { Strength } \\
\text { (IVIPa) (1) }\end{array}$} & \multirow{2}{*}{$\begin{array}{l}\text { Tensile } \\
\text { Yield } \\
\text { Strength(2) } \\
\text { (MHa) }\end{array}$} & \multirow[b]{2}{*}{$\begin{array}{c}\text { Elongation (3) } \\
(\%)\end{array}$} & \multirow[b]{2}{*}{$\begin{array}{l}\text { Reduction } \\
\text { in Area } \\
(\%)\end{array}$} & \multicolumn{2}{|c|}{$\begin{array}{l}\text { Keyhole Charpy } \\
\text { Impact Strength }\end{array}$} \\
\hline & & & & & $\begin{array}{c}\text { Test } \\
\text { Temperature } \\
\left({ }^{\circ} \mathrm{C}\right) \\
\end{array}$ & $\begin{array}{l}\text { Strenath } \\
(\mathrm{J})(4)\end{array}$ \\
\hline 0 & $497 \pm 91^{(5)}$ & & $<1$ & $<1$ & $\begin{array}{l}200 \\
450\end{array}$ & $\begin{array}{l}0.76 \\
0.71\end{array}$ \\
\hline 200 & $943 \pm 50$ & $593 \pm 9$ & $15.8 \pm 3.6$ & $14.3 \pm 3.6$ & $\begin{array}{l}200 \\
450\end{array}$ & $\begin{array}{r}3.5 \\
14.4\end{array}$ \\
\hline 500 & $951 \pm 8$ & $599 \pm 8$ & $20.4 \pm 3.1$ & $19.1 \pm 3.5$ & $\begin{array}{l}200 \\
450\end{array}$ & $\begin{array}{r}8.7 \\
19.3\end{array}$ \\
\hline 1000 & $958 \pm 12$ & $597 \pm 17$ & $20.5 \pm 9.4$ & $17.7 \pm 9.8$ & $\begin{array}{l}200 \\
450\end{array}$ & $\begin{array}{r}7.7 \\
27.0\end{array}$ \\
\hline 2000 & $958 \pm 8$ & $601 \pm 8$ & $18.8 \pm 2.9$ & $16.9+3.2$ & $\begin{array}{l}200 \\
450\end{array}$ & $\begin{array}{r}9.8 \\
27.9\end{array}$ \\
\hline
\end{tabular}

(1) $1 \mathrm{MPa}=0.145 \mathrm{ksi}$.

(2) At $0.2 \%$ offset.

(3) In one inch.

(4) 1 joule $=0.738 \mathrm{ft} \mathrm{lb}$.

(5) $95 \%$ confidence limits on mean.

W-3.5 Ni-1.5 Fe blend (six each at niobium levels of $0.12,0.70$, and 1.1 wt \%). The hars were isostatically pressed at $207 \mathrm{MPa}$, sintered in wet hydrogen at $1470^{\circ} \mathrm{C}$, and vacuum heat treated at $1200^{\circ} \mathrm{C}$ for four hours. Two bars of each composition were heated in argon at $1000^{\circ} \mathrm{C}$ for one hour and water quenched. For each alloy, tensile bars were machined from the quenched bars and from two heat-treated bars. Keyhole Charpy bars were also machined from two heat-treated bars. The properties obtained from these specimens are listed in Table 6; in addition, the impact data are plotted in Figure 3. Deterioration of properties with increasing niobium content is evident, and there appears to be no beneficial effect as a result of the quenching treatment. On the hasis of the data in Table 6 , it is further evident that niobium additions on the order of 1000 to $2000 \mathrm{ppm}$ are optimum.

\section{Blistering in High-Green-Strength Tungsten-3.5 Nickel-1.5 Iron Alloy}

To promote resistance to handling damage in the green-pressed state, certain tungsten powder is manufactured so as to possess a high measure of strength in the pressed but unsintered condition. A large quantity of high-green-strength (HGS) tungsten powder has been used to prepare W-3.5 Ni-1.5 Fe alloy at $\mathrm{Y}-12$; but, in order to prevent the formation of surface blisters during liquid-phase sintering (Figures 4 and 5), it is necessary that the hydrogen atmosphere contain water vapor. The moisture is added to the hydrogen by bubbling the gas through water before it enters the furnace. With the objective of promoting an understanding of the general sintering behavior of this alloy, experiments were run to determine how the blistering might otherwise be controlled. If the blistering were controlled, an inference as to the cause might be drawn. Considering that blistering 


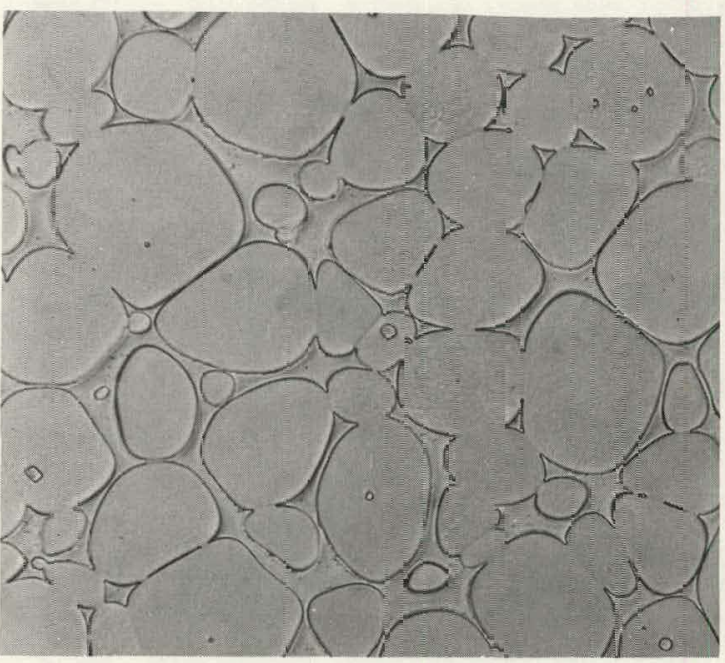

(a) Nith No Niobium.

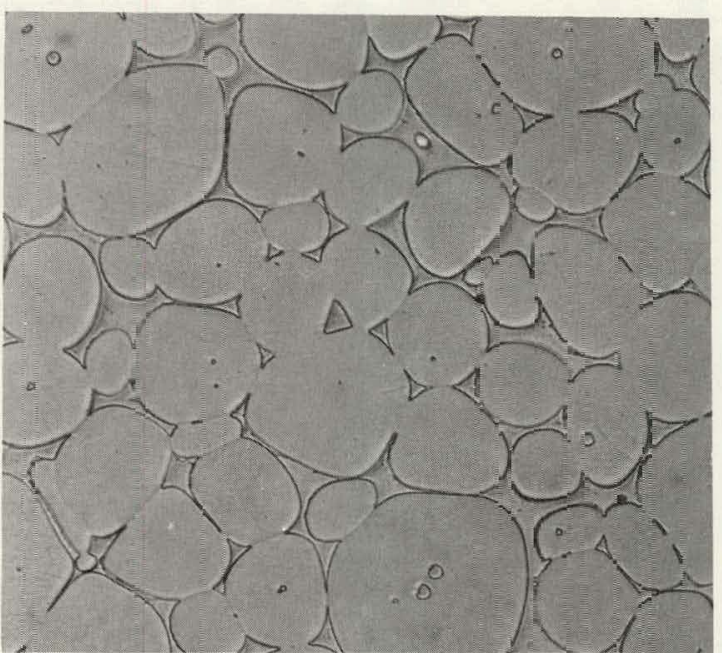

(b) With $230 \mathrm{ppm}$ Niobium

K490-

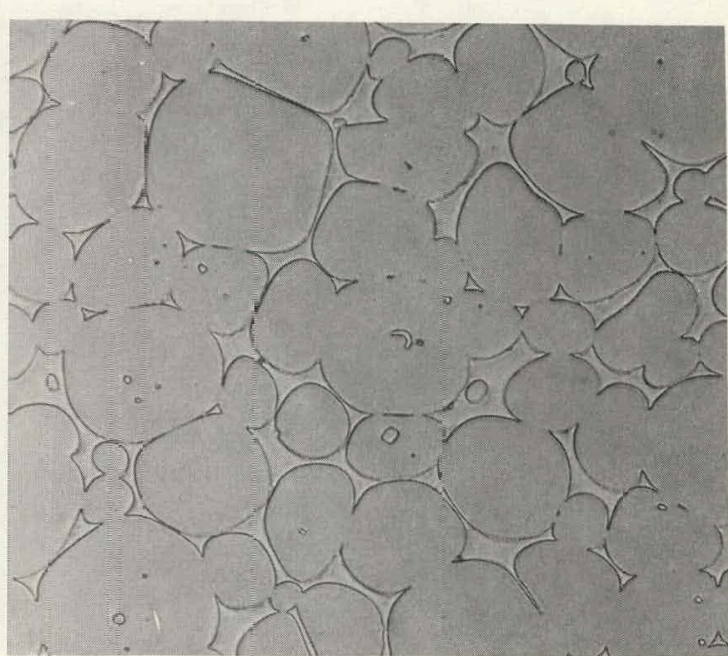

(c) With $500 \mathrm{ppm}$ Niobium.

K490-3

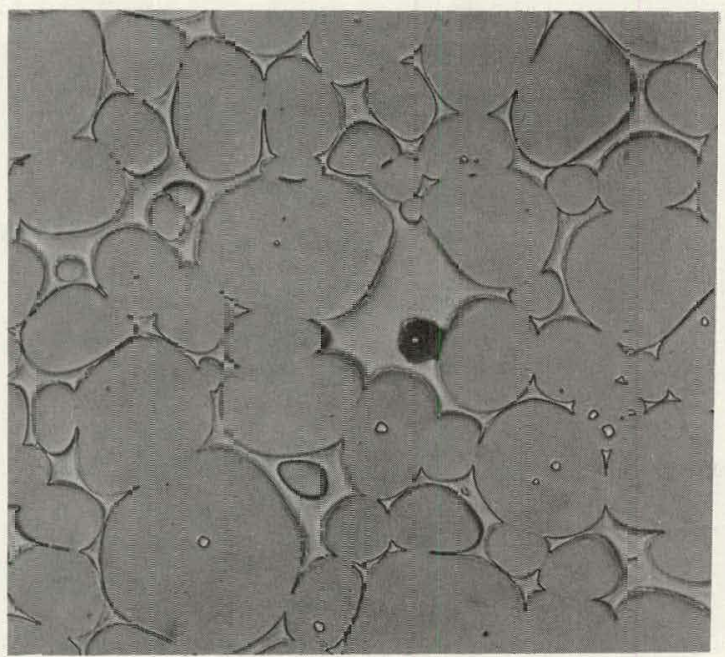

(d) With $100 \mathrm{Cp} \mathrm{n}$ Niobi.

$\ll 490-4$

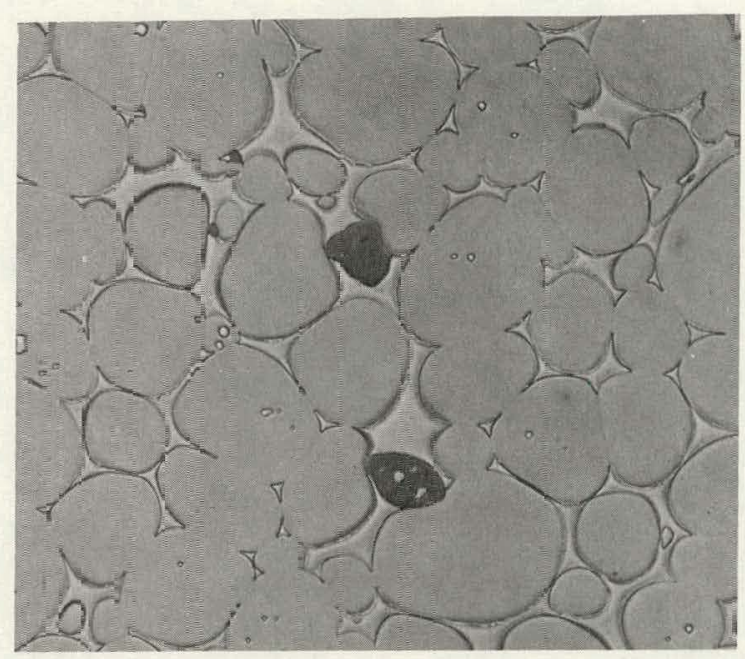

(e) Witt 2000 ppm Nicbium.

Figure 2. MICROSTRUCTURES OF REPROSESS $\equiv D$ TUNGSTEN-3.5 NICKEL-1.5 IRON ALLOYs WITH CERTAIN NIOE UM ADDITIONS. (Bright Field IIIUmination; 
Table 6

TENSILE PROPERTIES OF REPROCESSED TUNGSTEN-3.5 NICKEL-1.5 IRON

ALLOY WITH THREE LEVELS OF NIOBIUM AND IN TWO CONDITIONS OF HEAT TREATMENT

\begin{tabular}{cccccc}
\hline Condition & $\begin{array}{c}\text { Nominal } \\
\text { Niobium } \\
\text { Content } \\
(\text { wt \%) }\end{array}$ & $\begin{array}{c}\text { Ultimate } \\
\text { Tensile } \\
\text { Strength } \\
(\mathrm{MPa})(1)\end{array}$ & $\begin{array}{c}\text { Tensile } \\
\text { Yield } \\
\text { Strength(2) } \\
(\mathrm{MPa})\end{array}$ & $\begin{array}{c}\text { Elongation } \\
(\%)\end{array}$ & $\begin{array}{c}\text { Reduction } \\
\text { in Area } \\
(\%)\end{array}$ \\
\hline Heat Treated & 0.12 & $935 \pm 7^{(4)}$ & $573 \pm 21$ & $20.8 \pm 4.7$ & $18.3 \pm 1.9$ \\
Quenched & 0.12 & $940 \pm 16$ & $591 \pm 30$ & $24.5 \pm 6.4$ & $23.5 \pm 3.8$ \\
Heat Treated & 0.70 & $899 \pm 3$ & $559 \pm 4$ & $15.6 \pm 1.0$ & $13.2 \pm 1.0$ \\
Quenched & 0.70 & $902 \pm 3$ & $572 \pm 11$ & $16.8 \pm 2.0$ & $14.3 \pm 2.3$ \\
Heat Treated & 1.1 & $85.3 \pm 25$ & $5.32+15$ & $14.4+3.1$ & $12.9+3.1$ \\
Quenched & 1.1 & $865 \pm 7$ & $541 \pm 12$ & $13.4 \pm 2.9$ & $9.0 \pm 2.9$ \\
\hline
\end{tabular}

(1) $1 \mathrm{MPa}=0.145 \mathrm{ksi}$.

(2) At $0.2 \%$ offset.

(3) In one inch.

(4) $95 \%$ confidence limit on mean.

might be due to a gas that could be gettered by a reactive metal, titanium additions of 0 , 100,300 , and 900 ppm were added to HGS W-3.5 Ni-1.5 Fe alloy. Sintering was done in dry hydrogen at $1470^{\circ} \mathrm{C}$. Blistering was observed on all bars, but decreased in severity with increasing titanium content. The oxygen content of the bars containing titanium was greater than that of the bar with none added.

An addition of $1200 \mathrm{ppm}$ niobium to HGS tungsten alloy was also effective in reducing blistering, but did not completely eliminate it. In this experiment it was ascertained that the post-sintering vacuum heat treatment was required, in spite of the nıobıum additions, to cause the alloy to show maximum tensile test ductility. The tensile elongation in the as-sintered alloy was 1\%; after heat treatment this elongation increased to $11 \%$.

Since $1200 \mathrm{ppm}$ niobium was insufficient to completely eliminate blistering, an experiment was run in which the quantity added was increased to $5000 \mathrm{ppm}$. Concurrently, on the assumption that excessive oxygen might be contributing to blistering, an attempt was made to reduce the oxygen content of the HGS powder by subjecting it to flowing, dry hydrogen at $1200^{\circ} \mathrm{C}$ for six hours. Small experimental alloy bars were prepared from both the HGS powder with 5000 ppm niobium and the prereduced HGS powder. The component powders for each blend were

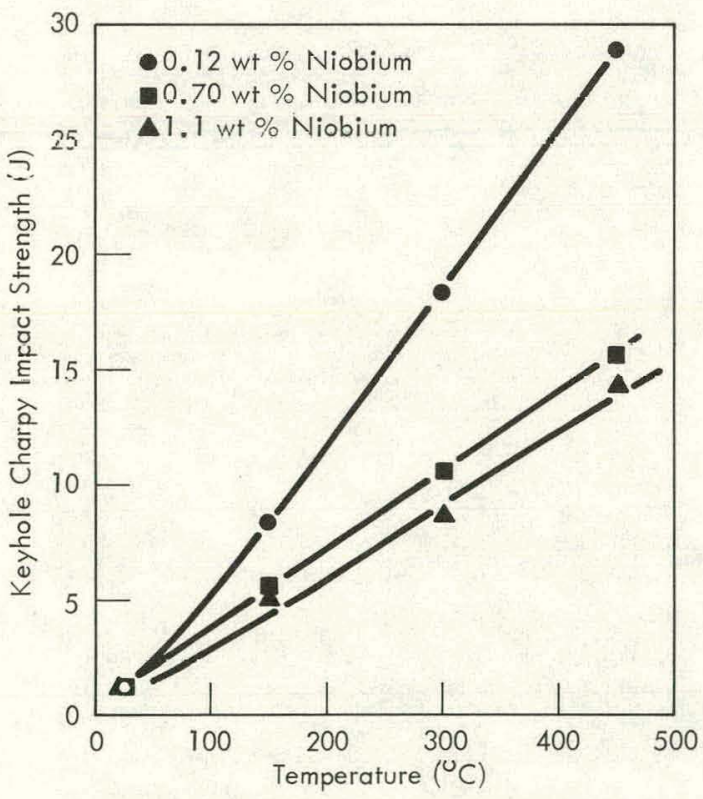

Figure 3. KEYHOLE CHARPY IMPACT STRENGTH AS A FUNCTION OF TEMPERATURE FOR REPROCESSED TUNGSTEN-3.5 NICKEL-1.5 IRON ALLOY WITH THREE LEVELS OF NIOBIUM. 


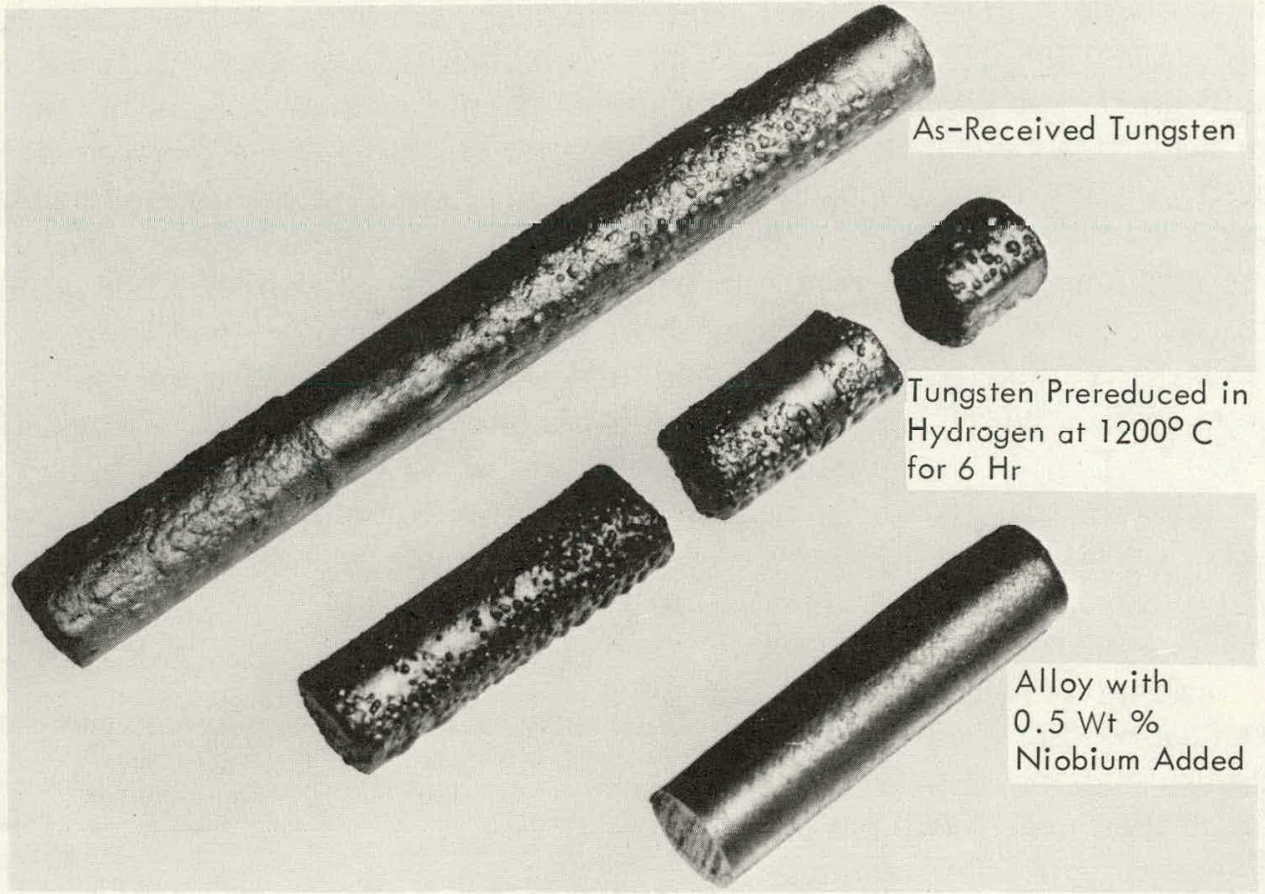

Figure 4. TUNGSTEN-3.5 NICKEL-1.5 IRON ALLOY PREPARED FROM HIGH-GREENSTRENGTH TUNGSTEN.

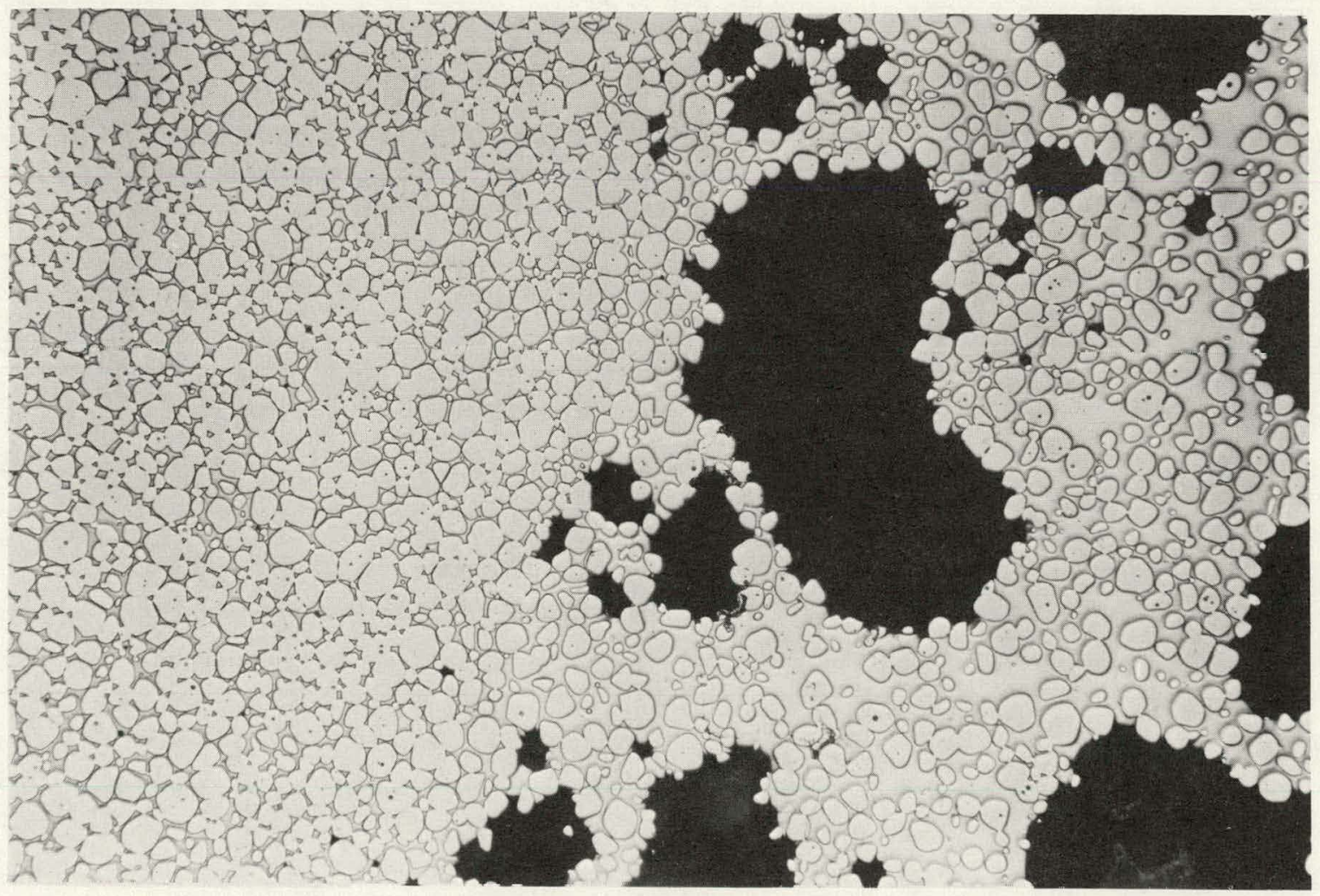

MS-72-0447-1

Figure 5. BLISTERING NEAR THE SURFACE OF HIGH-GREEN-STRENGTH TUNGSTEN-3.5 NICKEL-1.5 IRON ALLOY THAT HAD BEEN SINTERED IN WET HYDROGEN AND RESINTERED IN DRY HYDROGEN. (50X) 
mixed in a tungsten rod mill for four hours, isostatically pressed at $207 \mathrm{MPa}$, and sintered in dry hydrogen at $1485^{\circ} \mathrm{C}$. The as-pressed bar containing the prereduced tungsten was very fragile and broke into several pieces with normal handling. Neutron activation analyses of the two blends for oxygen gave 500 and $690 \mathrm{ppm}$, the latter value corresponding to the prereduced tungsten blend. Apparently, the prereduction treatment resulted in the loss of the high-green-strength property and activated the tungsten powder such that in spite of efforts to maintain it in an inert atmosphere, it rapidly reoxidized when only briefly exposed to air. Figure 4, Views b and $c$, show the appearance of the bars sintered from the two blends. The $5000 \mathrm{ppm}$ niobium addition effectively prevented blistering, but the prereduction treatment did not. The niobium-containing alloy had the chemical analysis summarized in Table 7. Its microstructure was similar to Figure 1, View b, and electron beam microprobe analysis of the gray inclusions was basically the same as that of the reprocessed tungsten alloy. Carbon, if present, was too low in atomir. numher to be detected by the microprohe.

With 1200 ppm niobium having been insufficient and $5000 \mathrm{ppm}$ ample to prevent blistering in HGS tungsten alloy, an experiment was run to determine the minimum required. From one blend of HGS W-3.5 Ni$1.5 \mathrm{Fe}$ powder, six batches were prepared containing 0,500, 1000, 2000, 4000, and 8000 ppm niobium. Each was mixed in a $V$ blender for one hour. One bar (approximately 19 $\mathrm{mm} \mathrm{D} \times 150 \mathrm{~mm} \mathrm{L)}$ was prepared from each batch, isostatically pressed at $207 \mathrm{MPa}$, and sintered in dry hydrogen at $14800 \mathrm{C}$. I he bars were vacuum heat treated at $1200^{\circ} \mathrm{C}$ for four hours after sintering. Figure 6 is a photograph of the bars with the varying levels of niobium and Table 8 contains their chemical analyses. There is a gradation in the amount of blistering from the 0 to $2000 \mathrm{ppm}$ bar which showed almost none. The 4000 and 8000 ppm bars showed no blistering. Tensile bars were machined from all bars in anticipation of there being a change in properties coincident with the elimination of blistering. As Table 9 shows, tensile elongation was

Table 8

CHEMICAL ANALYSIS OF HIGH-GREEN-STRENGTH

TUNGSTEN-3.5 NICKEL-1.5 IRON ALLOYS

WITH CERTAIN INIUUBIUIM AUUIIIUNS

\begin{tabular}{|c|c|c|c|c|}
\hline $\begin{array}{c}\text { Nominal } \\
\text { Niubium } \\
\text { Content } \\
\text { (ppm) }\end{array}$ & $\begin{array}{c}\text { Tungsten } \\
\text { (wt \%) }\end{array}$ & $\begin{array}{l}\text { Nickel } \\
\text { (wt \%) }\end{array}$ & $\begin{array}{l}\text { Iron } \\
\text { (wt \%) }\end{array}$ & $\begin{array}{c}\text { Niobium } \\
(\mathrm{ppm})\end{array}$ \\
\hline 0 & 94.64 & 3.53 & 1.42 & - \\
\hline 500 & 94.62 & 3.42 & 1.32 & 500 \\
\hline 1000 & 94.58 & 3.52 & 1.48 & 1000 \\
\hline 2000 & 94.50 & 3.55 & 1.48 & 2000 \\
\hline 4000 & 94.29 & 3.57 & 1.45 & 3900 \\
\hline 8000 & 94.62 & 3.44 & 1.30 & 7600 \\
\hline
\end{tabular}




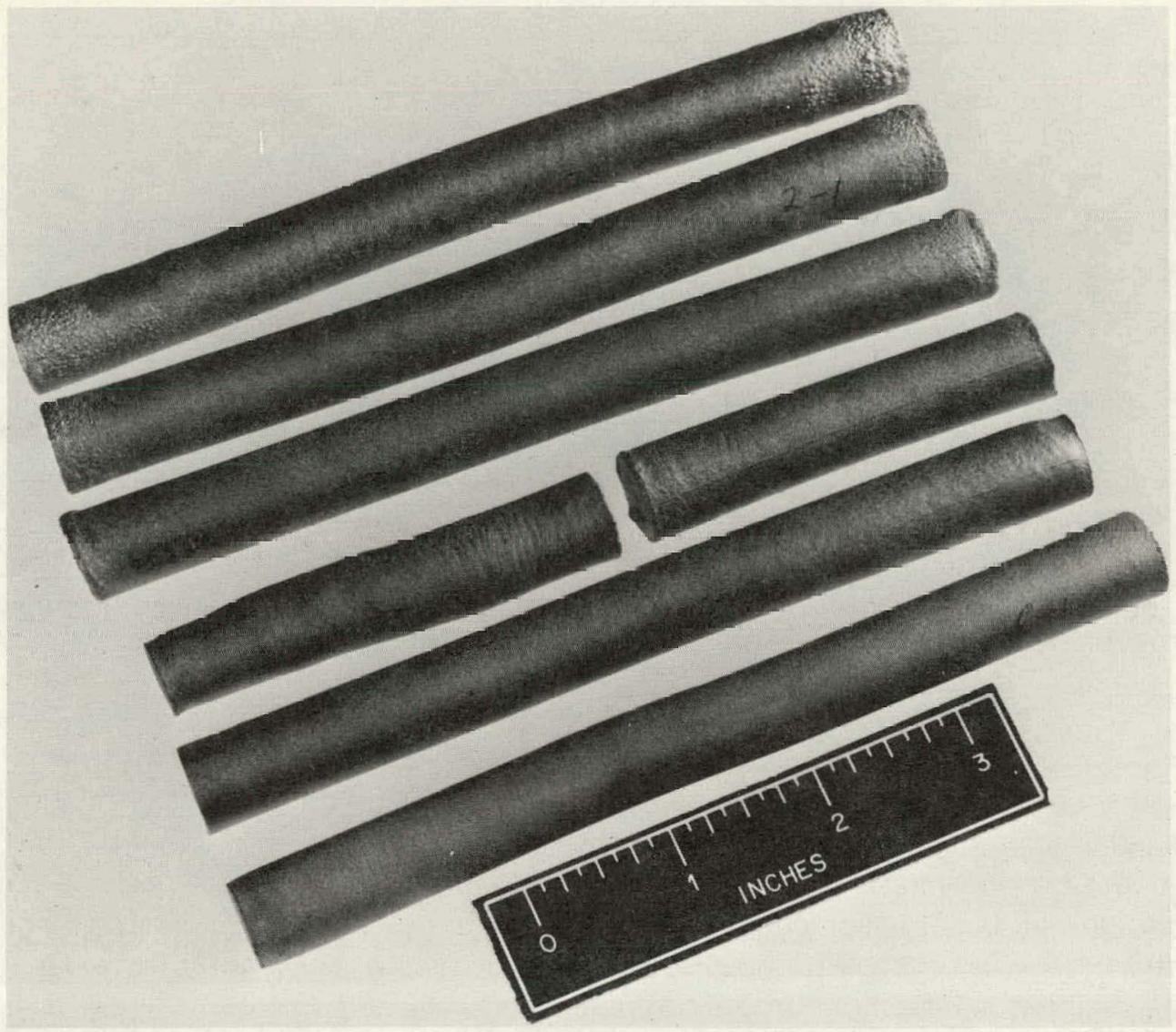

156454

Figure 6. BLISTERING ON HIGH-GREEN-STRENGTH TUNGSTEN-3.5 NICKEL-1.5 IRON ALLOY CONTAINING (FRUMI IUP IO BOTTOM) 0, 500, 1000, 2000, 4000, AND 8000 ppm NIOBIUM.

Table 9

TEINSILE YROPERTIES OF HIGH-GREEN-STRENGTH TUNGSTEN-3.5 NICKEL-1.5 IRON ALLOY WITH VARIOUS NIOBIUM ADDITIONS AFTER SINTERING IN DRY HYDROGEN

\begin{tabular}{rcccc}
\hline $\begin{array}{c}\text { Nominal } \\
\begin{array}{c}\text { Nobium } \\
\text { Level } \\
(\mathrm{npm})\end{array}\end{array}$ & $\begin{array}{c}\text { Ultimate } \\
\text { Tensile } \\
\text { Strength } \\
(\mathrm{MPa})\end{array}$ & $\begin{array}{c}\text { Tensile } \\
\text { Yield } \\
\text { Strength(1) } \\
(\mathrm{MPa})\end{array}$ & $\begin{array}{c}\text { Elongation(2) } \\
(\%)\end{array}$ & $\begin{array}{c}\text { Reduction } \\
\text { in Area } \\
(\%)\end{array}$ \\
\hline 0 & 975 & 639 & 23.8 & 24.1 \\
500 & 955 & 622 & 14.0 & 13.7 \\
1000 & 934 & 641 & 13.5 & 10.6 \\
2000 & 910 & 615 & 12.0 & 10.9 \\
4000 & 945 & 607 & 15.3 & 12.8 \\
8000 & 956 & 631 & 12.0 & 9.8 \\
\hline
\end{tabular}

(1) At $0.2 \%$ offset.

(2) In one inch. 


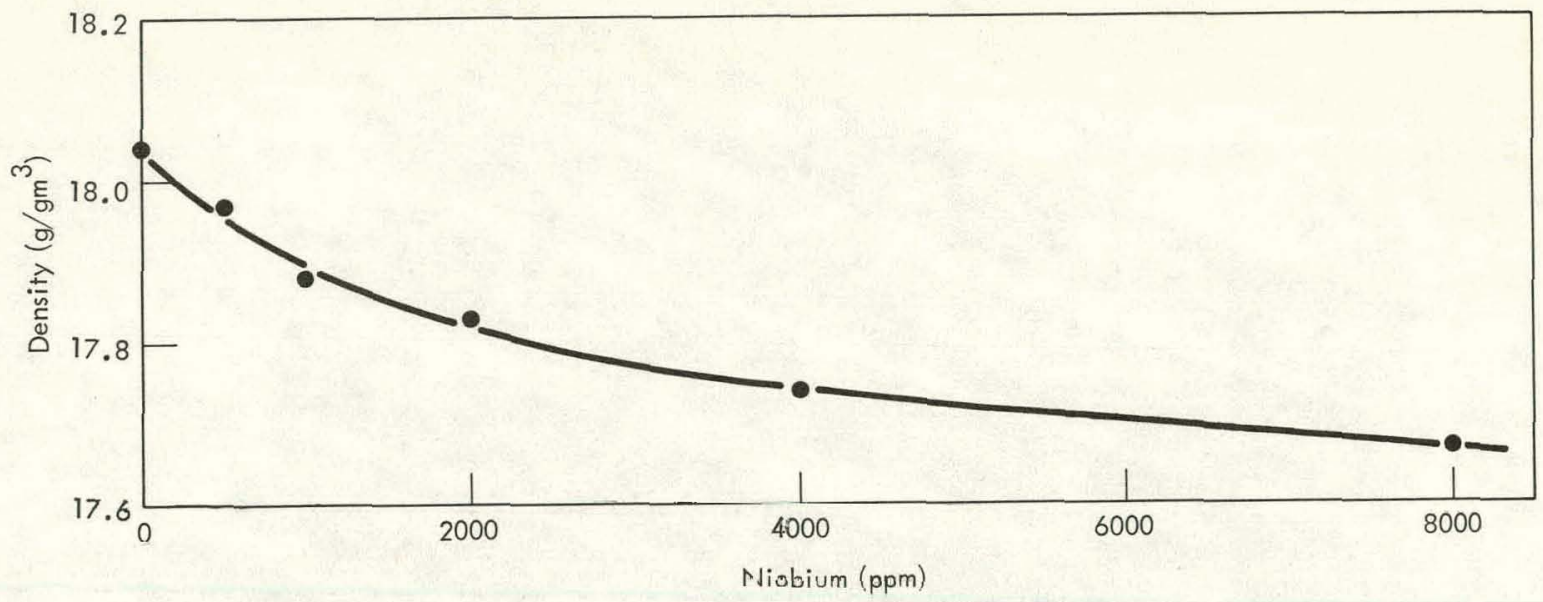

Figure 7. DENSITY AS A FUNCTION OF THE NIOBIUM CONTENT FOR NIOBIUM-CONTAINING HIGH-GREENSTRENGTH TUNGSTEN-3.5 NICKEL-1.5 IRON ALLOYS WITH BLISTERED SURFACE REMOVED.

greatest for the most severely blistered bar, then dropped to a near-constant lower level for all the other compositions. The effect of the niobium addition on the densily of the sintered alloy is revealed in Figure 7. Pieces of machined tensile bars were used as density specimens, so the densities were unaffected by the blisters which had been located near the surface of the bars and had been machined away. Because of the relatively small extent of blistering compared with what has been observed on other occasions (eg, Figure 4), it was felt that sintering might not have been quite complete. To check this possibility, half of a broken tensile bar of each composition was reheated in dry hydrogen to $1485^{\circ} \mathrm{C}$ for one hour. Blistering reoccurred to essentially the same absolute and relative extent as it had on the original bars. Again, the dividing line between blistering and the complete suppression of hlistering was between the 2000 and 4000 ppm niobium levels.

\section{DISCUSSION OF RESULTS}

\section{Low Tensile Ductility in Reprocessed Tungsten-3.5 Nickel-1.5 Iron Alloy}

These experimental results would tend to indicate that the role of reactive metal additions in increasing ductility in reprocessed $\mathrm{W}-3.5 \mathrm{Ni}-1.5 \mathrm{Fe}$ alloy is not related to the hydrogen embrittling effect. A vacuum heat treatment continues to be required for the attainment of maximum ductility, even in alloys with reactive metal additions. Effectiveness of the niobium must lie in its ability to combine with a small quantity of some impurity which normally segregates at the interface between the tungsten particles and matrix. With only 200 ppm niobium being enough to cause a very substantial increase in properties (Table 5), not only must the concentration of any undesirable impurities be low, but the niobium must be effectively dispersed to adequately react with them. Since the microstructures of Figure 2 do not show undissolved niobium for concentrations less than about $1000 \mathrm{ppm}$, and since properties are maximized in the alloys containing $1000 \mathrm{ppm}$ or less, it is evident that only the niobium dissolved in the alloy is effective in enhancing properties. The association of oxygen with the large residual niobium particles, then, gives what may be a misleading impression that the improvement in properties is a consequence of gettered 
oxygen. The oxygen analyses in Table 4 tend to support this conclusion because, in the alloys with improved properties, the oxygen contents of $9 \mathrm{ppm}$ and less compare favorably with what is observed in any liquid-phase-sintered W-3.5 Ni-1.5 Fe alloy with no niobium, whether it is ductile or brittle.

Niobium, as an alloying addition, beyond its effect in restoring ductility, leads to a lowering of tensile and impact properties, as noted in Table 6 and Figure 3. There is no beneficial effect to be gained from adding an amount in excess of that required to restore ductility.

\section{Blistering in High-Green-Strength Tungsten-3.5 Nickel-1.5 Iron Alloy}

When more than 2000 ppm niobium is added to HGS W-3.5 Ni-1.5 Fe alloy and sintering is done in dry hydrogen, the surface blistering which would occur in the absence of niobium is not ubserved. Sintering the alloy with no niobium in wet hydrogen accomplishes the same end. However, a difference exists in that the alloy with no niobium, sintered in wet hydrogen and then resintered in dry hydrogen, will blister; but the alloy with a niobium addition, sintered in wet hydrogen and resintered in dry hydrogen, will not blister. The impurities involved and the mechanism by which the blistering is suppressed are not known. Figure 5 suggests that the gas-producing reaction is initiated at the matrix/tungsten particle interface, and blisters form only near the surface where a relatively low pressure will deform the semimolten alloy. The low-pressure restriction may indicate the operation of a metal oxide-metal reduction reaction whose equilibrium condition is dependent upon the dew point of the hydrogen atmosphere and temperature-pressure conditions. In dry hydrogen, the reaction would proceed to produce a gaseous reaction product, but the presence of moisture would cause the equilibrium to be reversed.

Hypotheses as to the artion of the niobium dissolved in the matrix are that it may react with a gas-producing or high-vapor-pressure impurity, or it could conceivably disrupt the equilibrium of a metal oxidc-metal reaction or affer.t the distribution mode of a harmful impurity.

\section{CONCLUSIONS}

Several conclusions have been reached from this study:

1. Low concentrations of niobium metal have been shown to be effectivc additions for improving the mechanical properties and sinterability of W-3.5 Ni-1.5 Fe alloy prepared with certain grades of tungsten powder.

2. Other redulive hietals, such as titanium and zirconium, appear tn have a similar potential.

3. The solubility of niobium in the $\mathrm{W}-3.5 \mathrm{Ni}-1.5 \mathrm{Fe}$ composite is in the range of 500 to $1000 \mathrm{ppm}$, and most of this is dissolved in the matrix alloy.

4. Niobium conccntrations in amounts of 0.7 tn $1.1 \mathrm{wt} \%$ tend to deteriorate the tensile and impact properties of $\mathrm{W}-3.5 \mathrm{Ni}-1.5 \mathrm{Fe}$ alloy. 


\section{REFERENCES}

(1) Krock, R. H. and Shepard, L. A.; "Mechanical Behavior of the Two-Phase Composite, Tungsten-Nickel-Iron", Trans AIME, 227, pp 1127-1134 (1963).

(2) Snyder, W. B., Jr, Ludwig, R. L., and Northcutt, W. G., Jr; Liquid-Phase Sintered Tungsten Alloys; Oral Presentation to ASM Soutthern Industries Materials Conforoncc, Átlantä, Georgia; April 18-20, 1973. 


\section{Distribution}

Energy Research and Development Administration - Oak Ridge

Hickman, H. D.

Leed, R. E.

Zachry, D. S., Jr

\section{Holifield National Laboratory}

Weir, J. R., Jr

Oak Ridge Gaseous Diffusion Plant

Stief, S. S.

Wilcox, W. J., Jr

Oak Ridge Y-12 Plant

Alvey, H. E.

Bernander, N. K.

Burditt, R. B.

Burkhart, L. E.

Cadden, J. L.

Dodson, W. H.

Ebert, T. H.

Ellingson, R. D.

Fraser, R. J.

Gritzncr, V. B.

Jackson, V. C.

Jones, F. W.

Kahl, K. G.

Keith, A.

Kite, H. T.

Koger, J.W.

Ludwig, R. L. (5)

Lundin, M. I.

Mills, J. M., Jr

Northcutt, W. G., Jr

Phillips, L. R.

Schrever, J. M.

Smith, H. F., Jr
Smith, R. D.

Snyder, W. B., Jr

Stoner, H. H.

Tewes, W. E.

Tilson, F. V.

Yaggi, W. J./Googin, J. M.

Y-12 Central Files (5)

$Y-12$ Central Files (master copy)

$Y-12$ Central Files (route copy)

$Y-12$ Central Files $(Y-12 R C)$

Zerby, C. D.

Paducah Gaseous Diffusion Plant

Levin, R. W.

In addition, this report is distributed in accordance with the category UC-25, Materials, as given in the USERDA Standard Distribution Lists for Unclassified Scientific and Technical Reports, TID-4500. 